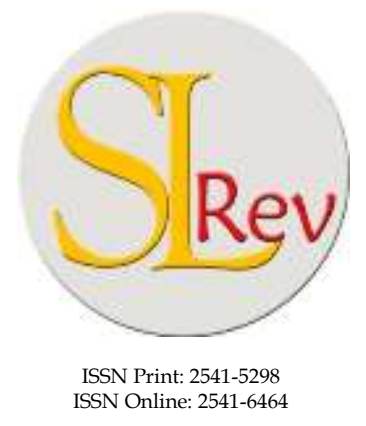

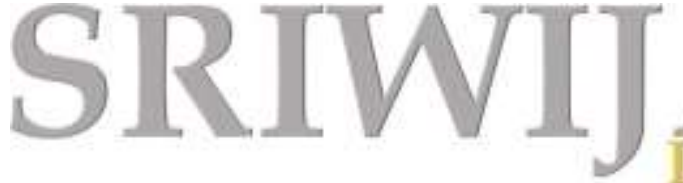
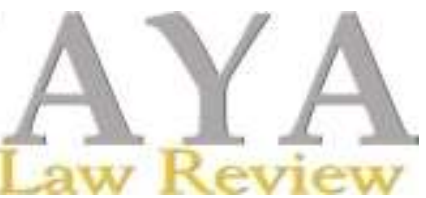

Editorial Office: Faculty of Law, Sriwijaya University

Jalan Srijaya Negara, Palembang, South Sumatra 30139, Indonesia.

Phone: +62711-580063Fax: +62711-581179

E-mail: sriwijayalawreview@unsri.ac.id| sriwijayalawreview@gmail.com

Website: http://journal.fh.unsri.ac.id/index.php/sriwijayalawreview

\title{
Does Religious Holiday Allowance Policy during Covid-19 Provide Legal Certainty?
}

\author{
Aries Harianto $^{\mathrm{a}}$ \\ a Faculty of Law, Universitas Jember, Indonesia. E-mail: dr.aries99@gmail.com
}

\begin{tabular}{ll}
\hline Article & Abstract \\
\hline $\begin{array}{l}\text { Keywords: } \\
\text { Contradictory; Gov- } \\
\text { ernment Policy; Legal } \\
\text { Certainty; Religious } \\
\text { Holiday Allowance; } \\
\text { Regulations. }\end{array}$ & $\begin{array}{l}\text { The Circular Letter of the Minister of Manpower No. M/6/HI.00.01/V/2020 } \\
\text { concerning the Implementation of Religious Holiday Allowance Payment } \\
\text { (THR) of 2020 in Companies during Covid-19 Pandemic is a regulation } \\
\text { expected to complete THR payment problems in this Pandemic situation. } \\
\text { However, normatively, this regulation raises new legal issues. This regula- } \\
\text { tion's provisions contradict the principle of legal certainty because it contra- } \\
\text { dicts the laws and regulations above it. Under the juridical normative type } \\
\text { of research, the results of this research found the emergence of legal conse- } \\
\text { quences due to industrial relations disputes for employment relations actors }\end{array}$ \\
$\begin{array}{l}\text { Received: Jul 20, 2020; } \\
\text { Reviewed: Jan 5, 2020; } \\
\text { Accepted: Jan 30, 2021; } \\
\text { Published: Jan 31, 2021. }\end{array}$ & $\begin{array}{l}\text { found that the Minister Circular Letter on THR Payment basically contra- } \\
\text { ficted the principle of legal certainty because the status does not belong to } \\
\text { DOI: }\end{array}$ \\
$\begin{array}{l}\text { 10.28946/slrev.Vol5.Iss1 } \\
\text { the statutory regulations, meaning that it has no force to be applied as statu- } \\
\text { tory regulations do. Based on the Statutory regulation, the minister Circular } \\
\text { Letter's legal status only applies to internal institutions which issue and be- } \\
\text { longs to technical and administrative arrangements. Thus, legal action as re- } \\
\text { search result recommended to the government is revoking the minister's cir- } \\
\text { cular letter on THR Payment. }\end{array}$
\end{tabular}

C2021; This is an Open Access Research distributed under the term of the Creative Commons Attribution License (https://Creativecommons.org/licences/by/4.0), which permits unrestricted use, distribution, and reproduction in any medium, provided the original works is properly cited.

\section{INTRODUCTION}

Labours always expect the Religious Holiday Allowance (THR) payment to welcome their religious holidays. However, the implementation of THR is sometimes out of their expected due to multiple interpretations on unclear regulations, workers' ignorance, incompetence of the company, entrepreneurs' delinquency, or the government policy errors. ${ }^{1}$ The spread of Corona Virus Disease (Covid-19) is developing rapidly, especially in Indonesia. Several economy sectors were affected by the Covid-19 pandemic in a short period, especially companies'

1 Taufiq Yulianto, "Langkah Hukum Terhadap Pelanggaran Pemberian Tunjangan Hari Raya Keagamaan,” Jurnal Orbith 12, no. 2 (2016): 112-16, http://dx.doi.org/10.32497/orbith.v12i2.776. 
employment relations sector. If it happens continuously, it will undoubtedly bring more negative impacts undoubtedly' welfare and the sustainability of the company's business. ${ }^{2}$ The Covid-19 pandemic has caused the companies to be unable to maximize their achievements, leading to defaults. ${ }^{3}$

The government issued several social policies to reduce the spread of Covid-19. The government's social policies greatly impact entrepreneurs and industries, especially on the production that the raw materials and markets are imported. This policy caused many companies or industries to experience a decrease in their incomes and even financial loss. ${ }^{4}$

The number of labourers in Indonesia on August 2018 amount to more than One Hundred million People (precisely 124,01 million labourers). This number shows almost half of Indonesian populations. It means the existence of labourers is vital for both government, companies and Indonesian people. Therefore, due to this significant role, legal protection for labourers is required, which is realized through material protection (welfare), namely the right to receive THR Payment. ${ }^{5}$

This research is significant and fundamental to resolve new problems during the Covid-19 pandemic to provide legal protection for workers and their families concerning THR payment as labour rights. This provision has been stated in the 1945 Constitution of the Republic of Indonesia Article 28D paragraph (2) that every person has the right to work and receive fair and appropriate compensation and treatment in an employment relationship. Article 28D paragraph (2) is the primary provision for regulating labourers and their families' welfare.

The THR, based on the Minister Circular Letter on THR Payment, is a non-wage income that must be paid by entrepreneurs to their labourers before the Religious Holiday. ${ }^{6}$ Normatively, THR is regulated in the Act No.13 of 2003 concerning Manpower. It is further elaborated by Government Regulation No.78 of 2015 concerning Wages (Government Regulation on Wages) and operationalized through Minister of Manpower Regulation No.6 of 2016 concerning Religious Holiday Allowance (Minister Regulation on THR).

It is stated clearly and explicitly that THR is a labour right. Both those with permanent status in employment relations with an Indefinite Time Work Agreement (PKWTT) and temporary labourers in a working relationship tied to a PKWT as non-wage income. The deadline for the employer to pay THR is seven days before the religious holiday. Rights are inherent in human life, which is owned, and existence can be used. A person owns these rights. Then he has the freedom

2 Daniel Marshal Sajou, "Kerenhapukh Milka Tarmadi Putri Dan Niken Febriana Dwi, "Peran Negara Atas Perlindungan Hukum Tenaga Kerja Indonesia Pada Masa Pandemi Covid-19"," Jurnal Syntax Transformation 1, no. 8 (2020): 2721-3854, https://jurnal.syntaxtransformation.co.id/index.php/jst/article/view/137.

3 Syafrida, Safrizal, and Reni Suryani, "Pemutusan Hubungan Kerja Masa Pandemi Covid-19 Perusahaan Terancam Dapat Dipailitkan," Pamulang Law Review 3, no. 1 (2020): 19-30, https://doi.org/10.32493/ palrev.v3i1.6532.

4 Mahendra Ridwanul Ghoni dan Kanyaka Prajnaparamitha, "Perlindungan Status Kerja Dan Pengupahan Tenaga Kerja Dalam Situasi Pandemi COVID-19 Berdasarkan Perspektif Pembaharuan Hukum," Administrative Law \& Governance Journal 3, no. 2 (2020): 2621-2781, https://doi.org/10.14710/alj.v3i2.314-328.

5 Suhartoyo, "Perlindungan Hukum Bagi Buruh Dalam Sistem Hukum Ketenagakerjaan Nasional," Administrative Law \& Governance Journal 2, no. 2 (2019): 326-36, https://doi.org/10.14710/alj.v2i2.326-336.

6 Riska Amalia Indahsari, "Perlindungan Hukum Terhadap Tenaga Kerja Outsourcing Mengenai Pembayaran THR Dalam Pengalihan Kerja,” Jurist-Diction 2, no. 1 (2019): 292-309, https://doi.org/10.20473/jd.v2i1.12113. 
to express it without any interference and pressure from any party. ${ }^{7}$ According to K. Bartens, right is a claim made by one person or group against other groups or society, while Darwin print stated that rights should be given to a person due to the position or status. ${ }^{8}$

The term labourer and workers have different meanings. In Act No.13 of 2003 on Manpower (Manpower Act), the two terms are used at once, namely: workers/labourers. The definition of worker is different from the labourer. The term labourer exists due to entrepreneurs' concept and vice versa, while workers are available for work. The worker becomes the master for himself and is not bound by the employment relationship between workers and employers. If the meaning of the terms labour, worker, and the labourer is compared and analyzed academically, it will be concluded that labour includes workers, while workers include labourers. Meanwhile, in the positive law, namely the UUK Article 1 point (3), it is implied that workers are equated with labour, in the sense that a worker/labourer is anyone who works and receives wages or other forms of remuneration. ${ }^{9}$ The Oxford Advanced Learners Dictionary defines "a worker is a person who works, especially one who does a particular kind of work". ${ }^{10}$ Based on this concept, the term labourer is an appropriate diction in studying employment relations because it provides a clear line of rights and obligations between labourers and entrepreneurs.

One of the rewards expected by labourers and their families was the payment of the THR. This allowance is given to labourers who celebrate the holy day following their respective religious teachings, such as Eid al-Fitr for Muslim, Christmas Day for Christians and Catholics, Wesak for Buddhist, and Nyepi for Hindu. However, the situation has now changed. Covid-19 pandemic triggers a variety of uncertainties. Changing government policy responds to social urgency, a declining market situation, and a reduction in the company's productivity and labour resources. All are inevitable. Moreover, there was a surge in THR complaints up to $68 \%$ compared to last year (2019). Even if the total number of complaints and THR consultations are combined, there will be an increase of almost $200 \%$.

Statistically, the Minister of Manpower, Ida Fauziyah, revealed that based on reports from the THR Complaints Post of Ministry of Manpower since 11-18 May 2020, 422 complaints had been received related to THR payments and 313 THR consultations, bringing the total number of complaints and consultations to 735. Apart from the Covid-19 pandemic, statistically, there has been a decrease in THR payments complaints over the last three years. In 2019 there were only 251 complaints, decreasing $21 \%$ compared to 2018, which recorded 318 complaints. Whereas in 2017 there were 412 complaints recorded. ${ }^{11}$

7 Abdul Azis, Aan Handriani, and Herlina Basri, "Perlindungan Hukum Hak Pekerja Pada Perjanjian Kerja Waktu Tertentu Dalam Ketenagakerjaan," Surya Kencana Satu: Dinamika Masalah Hukum Dan Keadilan 10, no. 1 (2019): 59-74, https://doi.org/10.32493/jdmhkdmhk.v10i1.3175.

8 I Wayan Agus Vijayantera, "Pengaturan Tunjangan Hari Raya Keagamaan Sebagai Hak Pekerja Setelah Diterbitkan Peraturan Menteri Tenaga Kerja Nomor 6 Tahun 2016," Jurnal Kertha Patrika 38, no. 2 (2016): 294.

9 Abdul Rachmad Budiono, Hukum Perburuhan (Jakarta: Permata Puri Media, 2009).

10 A S Hornby, Oxford Advanced Leaner's Dictionary (New York: Oxford University Press, 1995).

11 Ferry Sandi, "THR Tahun Ini Paling Parah, Pengaduan THR Melonjak 70\%," CNBC Indonesia, 2020, https://www.cnbcindonesia.com/news/20200520141059-4-159866/thr-tahun-ini-paling-parah-pengaduan-thrmelonjak-70.[ retrieved: June 8, 2020] 
The government is responsible for protecting welfare and justice to all people as formulated in the fourth paragraph of the Preamble to the 1945 constitution, further stated in article 3 of the 1945 constitution that Indonesia is a state of law so that state efforts in providing legal protection shall be based on the law. ${ }^{12}$ The Manpower Law regulates labourers before, at the time and after work period. Thus, this law shall provide legal order, certainty, justice and expediency, protection, and law enforcement. ${ }^{13}$

The government is demanded to be consistent in realizing the welfare of labourers, and entrepreneurs are asked to continue paying THR to their workers. Therefore, as of May 6, 2020, through the Ministry of Manpower, the government issued a Circular Letter of Manpower No. M/6/HI.00.01/V/2020 concerning the Implementation of Payment of Religious Holiday Allowance of 2020 in Companies during Covid-19 Pandemic (hereinafter referred to as SE). The regulation in the form of the circular letter was issued as a solution to provide certainty for labourers' right to get THR under uncertain productivity situation of the company. In other words, the Circular Letter is essential and fundamental as a form of government intervention. However, normatively, the existence of the SE creates the issue of legal uncertainty which will later create social problems in the form of industrial relations disputes.

Thus far, there has been no legal research that examines SE as the basis for workers' rights to receive THR, because SE is relatively new and was published in the Covid-19 pandemic situation. This research was conducted to find the consistency of legal certainty principle of labour and entrepreneurs agreement to determine the amount and time of THR payments for companies that cannot pay as stipulated in the Minister Circular Letter. Besides, it is also expected to find legal consequences for actors in an employment relationship. In this case, entrepreneurs and labours if the agreement concerning THR payment is not obtained and provide recommendations for future regulatory concepts as a solution of THR payment for underprivileged companies to be in line with the principle of legal certainty and to prevent industrial relations disputes.

Based on the above elaboration, the legal issues that arise in this study are: Based on the above elaboration, the legal issues that arise in this study are: 1) Does the agreement between labourers and entrepreneurs to determine the amount and time of THR Payment for companies that cannot pay as stipulated in the Minister Circular Letter contradict the principle of legal certainty?; 2) What are the legal consequences for entrepreneurs and the labourers if no agreement is reached concerning the Religious Holiday Allowance Payment?; 3) What is the THR payment solution for companies that cannot afford payment to avoid conflict with the principle of legal certainty?.

\section{RESEARCH METHOD}

The legal science is sui generis, ${ }^{14}$ it means the law is a particular kind of science. Characteristics (sui generis) of legal science are (a) analytical empiric, i.e., describing and analyzing legal con-

\footnotetext{
12 Muhammad Wildan, Nuridin, and Gufron Irawan, "Analisis Perlindungan Hukum Tenaga Kerja Dalam Perjanjian Kerja Waktu Tertentu," Justicia Sains: Jurnal Ilmu Hukum 4, no. 2 (2019): 174-88, http://dx.doi.org/10.24967/jcs.v4i1.414.

13 Laurensius Arliman S, "Perkembangan Dan Dinamika Hukum Ketenagakerjaan Di Indonesia," Jurnal Selat 5, no. 1 (2017): 74-87, https://ojs.umrah.ac.id/index.php/selat/article/view/215.

14 Tatik Sri Djatmiati Philipus M. Hadjon, Argumentasi Hukum (Yogyakarta: Gajah Mada University Press, 2005).
} 
tents and structures; (b) systematizing legal symptoms; (c) interpreting applicable legal substance, and (e) the practical meaning of legal science is related to the normative dimensions. ${ }^{15}$

Thus, the research type applied to resolve arising legal issues is a Normative Juridical method $^{16}$ i.e., a process of legal research carried to obtain argumentation, theory, and new concepts as a prescription to handle legal issues by examining and analyzing legislation and other legal materials. This research uses three approaches to reach the research objectives, namely Statutory Approach, Conceptual Approach, and Comparative Approaches.

The Statutory Approach is applied due to the possible contradiction between SE and the Regulations, explicitly regulating the THR Payment. The approach used provides some consequences on the analysis and examination of consistency and conformity between SE and the Act No.13 of 2003 concerning Manpower, Government Regulation No.78 of 2015 on Remuneration, and the Regulation of Minister of Manpower No. 6 of 2016 on Religious Holiday Allowance for Workers/Laborers in Company. The Conceptual Approach is carried out by tracing the views and doctrines that develop in the science of law sourced from experts or theories' opinions. Thus, ideas will be found that leads to various THR notions, understanding the principle of legal certainty, the concept of justice for labourers, the concept of agreement, the principles of agreement, and other legal concepts concerning legal issues research. The comparative approach is carried out by comparing the THR arrangements with similar policies in Malaysia. Malaysia is taken as one of the comparison objects because it is relatively close to Indonesia and affected by Covid19. It is expected that these three types of approaches used in the analysis will obtain results of research as a response to legal issues as a prescription that can be recommended to the legislators, especially to form THR regulations during the Covid-19 pandemic situation.

\section{ANAL YSIS AND DISCUSSION}

\section{Legal Certainty of the Minister of Manpower Circular Letter on THR Payment in the Covid-19 Pandemic Situation}

The Minister Circular Letter on THR Payment is urgent to save labourers' rights to receive THR. However, substantively, the issuance of the Circular Letter does not bring a new case. The SE potentially issues conflicts between labourers and employer, leading to disharmony of the employment relationship. Moreover, the Minister Circular Letter mandate is actually counterproductive to the principle of legal certainty.

Redburch opined a fairly fundamental opinion on legal certainty. There are four characteristics related to the meaning of legal certainty, namely (1) Law is positive, i.e., legislation; (2) law is based on facts, or established law is specific; (3) the statement shall be stated clearly to avoid misinterpretation, and it shall be applicable; (4) a positive law is not easy to change. ${ }^{17}$

15 DHM Meuwissen, 1994, "Pengembangan Hukum, Pro Justitia," Universitas Parahiyangan, Th.XII, No.1, January cited in Herowati Poesoko, Parate Executie Obyek Hak Tanggungan, DHM Meuwis (Yogyakarta: Laksbang Presindo, 2007).

16 Peter Mahmud Merzuki, Penelitian Hukum (Jakarta: Prenada Media, 2005).

17 Sulardi and Yohana Puspitasari Wardoyo, "Kepastian Hukum, Kemanfaatan, Dan Keadilan Terhadap Perkara Pidana Anak," Jurnal Yudisial 8, no. 3 (2015): 251-68, https://doi.org/http://dx.doi.org/10.29123/jy.v8i3.57. 
Radbruch stated that legal certainty is defined as a condition in which the law can function as a rule that must be obeyed. ${ }^{18}$ Legal certainty is a feature that cannot be separated from the law, especially for written legal norms. According to Fence M. Wantu, "without the value of legal certainty, the law is meaningless because it can no longer be used as a code of conduct for everyone." Legal certainty is defined as clarity of norms to be used as a guideline for people subject to this regulation. ${ }^{19}$ It means that the application of the law in society has been clear and firm to avoid misinterpretations. According to Van Apeldoorn, legal certainty means anything that can be determined by the law on tangible things. It is a guarantee that the law is enforced. Those who are entitled according to the law can obtain their rights, and those decisions can be implemented. It is justiciable protection against arbitrary action, which means that someone will get something that is expected in certain circumstances. In other words, legal certainty is a provision made by a country's legal instruments that are able to guarantee the rights and obligations of every citizen. It refers to a clear, permanent and consistent application of the law where any subjective circumstances cannot influence the implementation. According to Gustav Radburch, legal certainty principle belongs to the fundamental value of the law. Based on this principle, the law shall be made in written form to reveal its certainty. The existence of this principle is essential since it guarantees the clarity of an existing positive legal product. ${ }^{20}$

Based on the legal certainty concept above, the Minister Circular Letter is an authoritative decision having a written legal character. It regulates government policies in terms of THR payments during the Covid-19 pandemic. Thus the aspect of certainty is an interest that must be put forward. It is expected that there will be no multiple interpretations of legal certainty implementation. However, in the scope of industrial relations, legal certainty should consider the aspect of justice. If the aspect of justice is negated, the purpose of labour law, which is oriented to create legal protection and labour justice will not be achieved. ${ }^{21}$

Working in the dimension of religiosity is a manifestation of worship to get rightful results to meet individual and family needs as a right to life. Individually, labourers are human beings who are integrated with their religious and cultural beliefs. If Eid al-Fitr is a moment of religiosity, the cultural dynamics called Lebaran (Eid) is following. Workers celebrate Eid with a variety of events. Indeed, it requires additional costs. THR is a component that expected by workers for the need of Eid al-Fitr. At the same time, it is a moral obligation for entrepreneurs to realize the commitment and consistency of carrying out the First Principle, the Believe in One God. This commitment reflects the implementation of the Pancasila Industrial Relations Concept (hereinafter referred to as HIP) as a guideline for labours and entrepreneurs in employment rela-

18 R. Tony Prayogo, "Penerapan Asas Kepastian Hukum Dalam Peratran Mahkamah Agung Nomor 1 Tahun 2011 Tentang Hak Uji Materiil Dan Dalam Peraturan Mahkamah Konstitusi Nomor 06/PMK/2005 Tentang Pedoman Beracara Dalam Pengujian Undang-Undang,” Jurnal Legislasi Indonesia 13, no. 2 (2016): 191-202.

19 Tata Wijayanta, "Asas Kepastian Hukum, Keadilan Dan Kemanfaatan Dalam Kaitannya Dengan Putusan Kepailitan Pengadilan Niaga,” Jurnal Dinamika Hukum 14, no. 2 (2014), http://dx.doi.org/10.20884/ 1.jdh.2014.14.2.291

20 Mario Julyano and Aditya Yuli Selisyawan, "Pemahaman Terhadap Asas Kepastian Hukum Melalui Kontruksi Penalaran Positivisme Hukum,” Jurnal Crepido 1, no. 1 (2019): 13-22, https://doi.org/10.14710/crepido.1.1.1322.

21 Aries Harianto, "Makna Tidak Bertentangan Dengan Kesusilaan Sebagai Syarat Sah Perjanjian Kerja" (Brawijaya, 2013). 
tions. The HIP concept is a guideline containing the values of Pancasila as the integrity of the parties to build harmony, especially regarding the implementation of the rights and obligations of the parties in the working relationship. Thus, the THR is a labour right that must be given or is not agreed upon. Meanwhile, the government regulation on THR in the Minister Circular Letter states it is to be agreed upon.

The Issuance of the Minister Circular Letter allows entrepreneurs to pay THR gradually, and for the entrepreneurs who cannot afford the THR can postpone the payment. It could even allow entrepreneurs not to pay the THR at all. Whereas in fact, THR Payment is an obligation as situated in the Minster of Manpower Regulation number 6 of 2016 and Government Regulation on Wages number 78 of 2015. These two legal products do not allow postponement and instalment system for THR payment. This fact shows disconformity of Minister Circular Letter and the legislations. Minister Circular Letter tends to favour employers than workers. The position of Circular Letter is subordinate to the legislations on Manpower. For it shall not contradicts the provision of the legislation. The Minister Circular Letter do not have a standard form such as the statutory regulations. Therefore, it is not classified as legislation ${ }^{22}$ and cannot be used as a legal basis. ${ }^{23}$ It is only a form of policy regulation that cannot be referred to laws and regulations because there is no legislation regulating the policy regulations. Act Number 12 of 2011 on Establishment of Laws and Regulations does not provide a comprehensive definition of policy regulations. It shows that policy regulation is not a legal issue in establishing the Laws and Regulations Act. ${ }^{24}$ The type of Indonesian Manpower Act as a means of labourer protection is corporate law. In this law, the protection of works is regulated through legislation. ${ }^{25}$ In obtaining services through law availability as a product of legislation, labourers must be protected to create justice. This justice will lead to peace, welfare, and prosperity. ${ }^{26}$ Argumentation providing the basis for justice for workers in the legislation to provide justice for labourers basically emphasizes that the Minister Circular Letter is not a proper foundation to regulate THR payment.

The basic concepts of Minister Circular Letter on THR Payment are made to build a shared understanding between labourers and entrepreneurs due to Covid-19 pandemic. Though in emergencies, there has never been a common understanding between workers and employers. Labours and entrepreneurs as business actors, are always in diametric (opposite) positions. Labourer only has power-driven by the passions of responsibility to support the family. In contrast, entrepreneurs have capital, assets, production equipment, relations and access to all capitalistic

22 Irwan Adi Cahyadi, "Kedudukan Hukum Surat Edaran Mahkamah Agung (SEMA) Dalam Hukum Positif Di Indonesia," Jurnal Hukum 3 (2014), http://hukum.studentjournal.ub.ac.id/.

23 Nanang Rudi Hartono and Amalia Suci Ramadhani, "Tinjauan Yuridis Kebijakan Work From Home Berdasarkan Undang-Undang Ketenagakerjaan,” Jurnal Supremasi 10, no. 2 (2020), https://doi.org/10.35457/supremasi.v10i2.1158.

24 Victor Imanuel W. Nalle, "Kewenangan Yudikatif Dalam Pengujian Peraturan Kebijakan (Kajian Putusan Mahkamah Agung Nomor 23 P/HUM/2009)," Jurnal Yudisial 6, no. 1 (2013): 33-47, http://dx.doi.org/10.29123/jy.v6i1.117.

25 Ujang Charda S, "Karakteristik Undang-Undang Ketenagakerjaan Dalam Perlindungan Hukum Terhadap Tenaga Kerja," Jurnal Wawasan Hukum 32, no. 1 (2015): 7, http://dx.doi.org/10.25072/jwy.v32i1.86.

26 Alzikri Fakhrurraji, "Implementasi Perundang-Undangan Ketenagakerjaan Terhadap Buruh Pasar Ditinjau Dari Perspektif Keadilan," Jurnal Hukum Sekolah Tinggi Ilmu Hukum Muhammdiyah Aceh Tengah 4, no. 1 (2018): 31-44, https://doi.org/10.32661/resam.v4i1.7. 
lines. Labourers try to earn a profound income by removing the smallest energy. On the contrary, entrepreneurs are always oriented to get profits as much as possible by spending the smallest cost. The conception of opposite interactive interest is a value. Thus, if the Circular Letter expects a common understanding of employment relations, it is philosophically far from employment relations' principle rules. Point (1) of the Minister Circular Letter on THR Payment stated that the Governor has to ensure that the THR payments are made under the statutory regulations. At the same time, point (2) explicitly states that if the company is unable to afford THR payment at the time specified under statutory provisions, the solution to the problem should be obtained through a process of dialogue between entrepreneurs labourers. The dialogue process is carried out in a kinship way, based on transparent internal company financial statements and good faith to reach an agreement. Explicitly or implicitly, there was no explanation for the limitations of employers' inability to pay THR for labourers. The entrepreneur may state the inability unilaterally, without the support of data statistics and facts. Statement of employers' inability to pay THR without audit evidence of public accountants is because the minister Circular Letter does not mention. There is no legal space for labourers to exert pressure to justify a statement of incompetence from employers. In the perspective of justice, the Circular Letter does not accommodate the principle of proportionality. The principle of proportionality is the embodiment of "the agreement justice" doctrine which corrects the domination of the principle of freedom of contract, which in some cases creates injustice. ${ }^{27}$ Since in the agreement, labours' position is subordinate to employers, they have limited bargaining power to determine the THR payment as their rights.

The minister Circular Letter's essential is to provide a solution for an entrepreneur who is unable to pay the holiday allowance, which is based on the regulation. It gives solution for labourers-entrepreneurs to have a negotiation. For, the dialogical process occurred between the parties. This concept is known as bipartite. The mechanism of bipartite is contractual. The output is agreement bound in the form of agreements/contracts. According to Sudikno Mertokusumo, "an agreement is a legal relationship between two or more parties based on an agreement to bring about a legal consequence. Thus both parties agree to determine the rules, or rights and obligations that bind them to be obeyed and carried out.",28

According to the principle of Pacta Sun Servanda, agreements which in this case are carried out by labours and employers normatively become the law for the parties making them. When the agreement against the laws and regulations, then it will be null and void.

The legal terms of the agreement based on Article $1320 \mathrm{BW}$ are: first, there is a will agreement, second, the ability to act according to law, third, a particular object or subject, and fourth, a cause that is not prohibited by statutory regulations. The fourth point defines that a contract must be made under applicable law. For, no contract should be made to do things against the law. ${ }^{29}$ The agreement contents are not prohibited by law or do not conflict with decency/public

27 Agus Yudha Hernoko, "Asas Proporsionalitas Sebagai Landasan Pertukaran Hak Dan Kewajiban Para Pihak Dalam Kontrak Komersial," Jurnal Hukum Dan Peradilan 5, no. 3 (2016): 447-66, http://dx.doi.org/ 10.25216/jhp.5.3.2016.447-466.

28 Sudikno Mertokoesumo, Mengenal Hukum (Yogyakarta: Liberty, 1999).65

29 Aries Harianto, Hukum Ketenagakerjaan, Makna Kesusilaan Dalam Perjanjian Kerja (Yogyakarta: Laksbank, 2016). 151 
order. ${ }^{30}$ Besides, Article $1335^{31}$ of the Civil Code also stipulates that an agreement made without motive or made for false or prohibited reason is not legally binding. The agreement's legal conditions are rational that the agreement resulted in the employment relationship regarding the payment of THR is null and void because there is no statutory regulation ${ }^{32}$ mandating a consensus of labourers and employers to be involved in an agreement.

\section{Legal Consequences for not Achieving the Agreement}

Act Number 2 of 2004 on Industrial Relations Disputes Settlement (hereinafter referred to as UU-PPHI) regulates the mechanism of industrial relations disputes settlement. According to the UU-PPHI, it is stated that industrial relations disputes are dissent argumentations which result in disagreement between employers or employers' associations and workers/labourers or trade/labour unions. It is due to disputes of rights, interest, termination of employment and disputes between trade/labour unions in one company. ${ }^{33}$ THR normatively has legal certainty because the government Regulation regulates its existence. When an agreement is not obtained, then industrial relations disputes occur in the category of rights disputes. Rights disputes are disputes that arise because the rights are not fulfilled due to differences in the implementation or interpretation of statutory provisions, work agreements, company regulations, or collective working agreements. ${ }^{34}$

The SE instructs underprivileged entrepreneurs to negotiate because the legislation does not regulate. It will normatively lead to disagreement. Thus, the bipartite mechanism is a solution. The Act No 2 of 2004 on Industrial Relations Disputes Settlement Article 3 paragraphs (1) and (2) stipulated that "industrial relations disputes must be resolved in advance through deliberative bipartite negotiations to reach consensus." It must be completed no later than 30 (thirty) working days from the date negotiations started. ${ }^{35}$ The negotiating parties in bipartite are the labourers and entrepreneurs. If both parties approved, then a mutual agreement is made and submitted to the Industrial Relations Court through the District Court. This mutual agreement binding and legal, and the parties must implement it. Suppose one of the parties does not implement the agreement. In that case, the injured party can submit an application for execution to the Industrial Relations Court at the District Court in the area the mutual agreement registered to obtain an execution decree.

When a compromise is not obtained through bipartite negotiation, the parties must record their disputes to the local labour office. Article 4 paragraph (1) UU-PPHI shows that when bipartite negotiations fail as referred to in Article 3 paragraph (3), one or both parties register their dispute to the local agency. The parties responsible for the human resources field by

30 "Article 1337 of the Civil Code" (n.d.).

"Article 1335 of the Civil Code" (n.d.).

"The Act No. 13 of 2003 on Manpower along with Regulations Other than Circular of the Minister of Manpower No.M/6/HI.00.01/V/2020 Concerning the Implementation of the Religious Holiday Allowance (THR) of 2020 in the Company during Covid-19 Pandemic" (n.d.).

33 “Act No. 2 on Industrial Relations Disputes Settlement, Article 1 Paragraph 1” (2004).

34 Act No. 2 on Industrial Relations Disputes Settlement, Article 1 Paragraph 1.

35 “Act No. 2 on Industrial Relations Disputes Settlement Article 3 Paragraphs (1) and (2)" (2004). 
attaching evidence that bipartite negotiations have been carried out. ${ }^{36}$ After receiving the recording of one or more parties, the authorized agency should offer the parties to determine the settlement process, i.e., through conciliation or arbitration. However, regarding its effectiveness and efficiency, workers tend to avoid both mechanisms. The labourers tend to choose industrial relations mediation. Article 8 of the UU-PPHI stipulated that "Mediators carry out the settlement of disputes through mediation in each office of the agency responsible for the human resources sector. ${ }^{37}$ The process is relatively similar to bipartite; mediation requires mutual agreement between the parties, and submit to the Industrial Relations Court of the District Court through the local district court.

When the non-litigation mechanism cannot resolve the industrial disputes, the litigation process is taken, namely the court settlement. The settlement process is relatively similar to a civil trial. However, suppose labourers are aware of their right to receive Religious Holiday Allowance, supported with understanding labour regulations, and have skills to carry out both litigation and non-litigation proceedings. In that case, the Circular Letter causes high statistical industrial disputes. The Ministry data, Directorate General of Industrial Relations Development and Workers' Social Security (hereinafter referred to as Dirjen PHI and Jamsos) informed that there are 826 mediators at the central and regional levels. At the same time, the number of supervision objects reached 297.743 companies. ${ }^{38}$ Indeed, this imbalance belongs to resource problems that add to industrial relations disputes on THR payment regulations' legal uncertainty. Uncertainty will create dissatisfaction. Labourers' dissatisfactions will initially be expressed through complaints, but if the complaint is not resolved, then a dispute will arise. This unresolved dispute will develop into industrial disputes and even have the potential to trigger a work strike. A high level of dissatisfaction will tend to increase the potential for strikes. ${ }^{39}$

In the industrialization era, the industrial dispute settlement becomes more complicated. It requires an institution that supports a dispute resolution mechanism that is fast, fair, and inexpensive. $^{40}$ Act number 2 of 2004 on Industrial Relations Dispute Settlement is not substantially on labourers side to resolve industrial relations dispute. This Act's characteristic that put labourers as a weak party that shall be protected and guarantee the equality of labourers and entrepreneurs is only wishful thinking. ${ }^{41}$ Besides, the Act relies heavily on civil procedural law. Therefore the claims filed by labourers are often rejected due to formatting and systematic errors. Most workers do not understand the correct format of a lawsuit or attorney due to their

36 "Act No. 2 on Industrial Relations Disputes Settlement Article, Article 4 Paragraphs (1) and Article 3 (3)." (2004).

37 "Act No. 2 on Industrial Relations Disputes Settlement Article 8" (2004).

38 Ministry of Manpower's Public Relation Bureau, "Kemnaker: Pegawai Mediator Hubungan Industrial SiapSiaga Kawal Posko THR,” 2020, https://kemnaker.go.id/news/detail/.[ retrieved: June 23, 2020]

39 Jemadi and Siti Noor Hidayati, "Analisis Faktor-Faktor Yang Mempengaruhi Potensi Mogok Kerja Karyawan Di Yogyakarta," Jurnal Maksipreneur 1, no. 2 (2012): 46, http://dx.doi.org/10.30.588/jmp.v1i2.74.

40 Hazar Kusmayanti, Agus Mulya Karsona, and Efa Laela Fakhriah, "Penyelesaian Perselisihan Hubungan Industrial Melalui Pengadilan Hubungan Industrial Pengadilan Negeri Padang Kelas I (A)," Jurnal Hukum Acara Adhaper 6, no. 1 (2020): 37.

41 Sugeng Santoso Hakim, “Kekhususan Hukum Acara Pengadilan Hubungan Industrial,” Jurnal Hukum Jatiswara 34, no. 1 (2019): 11-25, https://doi.org/10.29303/jaiswara.v34i1.189. 
limitations. They do not have sufficient economic conditions to pursue such a lengthy litigation path. $^{42}$

The above analysis shows that law enforcement on THR payment has not reached the desired expectation. This fact is caused by two factors: 1) limited quality and quantity of law enforcers, i.e., labour inspection. 2)several weaknesses of the law material that lead to legal vacuum, legal injustice and uncertainty. ${ }^{43}$

\section{The Solution of THR Payment for Companies that Cannot Afford Payment to Avoid Con- flicting with Legal Certainty Principle}

The regulation is made to resolve community issues. The Covid-19 pandemic has effected work relations. This pandemic affects the company's profits, making it difficult for the company to survive. Although the company can survive, it will take rationalization in Termination of Employment known as Termination of Employment (PHK) for labourers. The Deputy Chairperson of Indonesian Chamber of Commerce and Industry (KADIN), the Micro, Small, and Medium Enterprises (MSMEs) division, Suryani Motik stated that the workers terminated due to the Corona Virus Disease (Covid-19) pandemic reached 15 million people. This number is higher than the amount released by the Minister of Manpower as many as 2,8 million on April 20, 2020. It is because the number of MSMEs affected by Covid-19 has not been added. ${ }^{44}$

Other than PHK, the entrepreneurs have to pay the Religious Holiday Allowance for workers. The Circular Letter is issued as government intervention to relieve the employer's burden. However, it raises a new problem since it is contrary to the Legislations. The morality perspective views that the SE is not sufficient to build work relations harmony. The Circular Letter was not made to anticipate the laws and regulations because of the limited validity scope. The substance does not reduce the volume of labour rights but helps reducing employers burden. In the norm of legislation, SE is made and applies for internal regulations. At the same time, the Circular of the Minister of Manpower annulled the enactment of the legislation. Regarding the aspect of the purpose of SE, it violates the rules. It is violating the rules because basically, the SE is not a statutory regulation. As stipulated in Article 7 paragraph (1) of the Act No. 12 of 2011 on the Formation of Legislative Regulations, this hierarchy of laws and regulations was inspired by Hans Kelsen's Theory of the Hierarchy of Norms. ${ }^{45}$

The rational formula on THR should not change the basic principles that have been regulated in the legislation, both UUK, PP No.78 of 2015 and Permenaker No.6 of 2016. The Ministerial Decree as an authoritative decision is merely informative, which is imperative for the government to help employers realize their moral commitments to give THR to labourers. In other

42 Haikal Arsalan and Dinda Silviana Putri, "Reformasi Hukum Dan Hak Asasi Manusia Dalam Penyelsaian Perselisihan Hubungan Industrial," Jurnal HAM 11, no. 1 (2020): 40, http://dx.doi.org/ 10.30641/ham.2020.11.39-50.

43 Luthvi Febryka Nola, "Pengaturan Dan Penegakan Hukum Tinjangan Hari Raya Untuk Pekerja," Info Singkat Hukum IV, no. 16 (2012): 1-4.

44 CNN Indonesia, "Bukan 2 Juta, Kadin Sebut Korban PHK Akibat Corona 15 Juta," CNN Indonesia, 2020, https://www.cnnindonesia.com/ekonomi/20200501181726-92-499298/bukan-2-juta-kadin-sebut-korban-phkakibat-corona-15-juta. [retrieved: June 17, 2020]

45 Jimly Assadiqy and Ali Safa'at, Teori Hans Kelsen Tentang Hukum (Jakarta: Sekretariat Jenderal dan Kepaniteraan Mahkamah Konstitusi RI, 2006). 
words, employers are still burdened with the obligation to pay THR according to applicable regulations. Government intervention through the ministerial decree is a commitment to provide 'subsidies' for entrepreneurs affected by the Covid-19 pandemic over the nominal shortfall of THR payments given to labourers. The findings of the calculation of the existing shortfall result from other parties that can be accounted for. In order to maintain objectivity, public accountants usually involved. Technically, through a Ministerial Decree, employers must be audited to find out the entrepreneur's nominal capability and the number of subsidized bailouts that the government must bear. Even at the scheduling level, the THR nominal payment not paid by the entrepreneur is scheduled as an entrepreneur's debt. Repayment of debt is the responsibility of the government. This idea is a manifestation of the government's consistency in realizing the Pancasila Industrial Relations' values and the constitutional goal of the welfare of workers and their families. Moreover, this pandemic situation causes business uncertainty, while the labourers are demanded to fulfil their needs. This fact is the state's constitutional responsibility as in the concept of the welfare state law theory in which the state needs to intervene in the administration of people's welfare. The state is an Instrument of Power and an Agent of Services, i.e., the labour community.

\section{CONCLUSION}

The agreement as a solution for payment of THR for companies that can afford to pay as stipulated in the Minister Circular Letter on THR Payment concerning the Implementation of Religious Holiday Allowance Payment in 2020 during the Covid-19 Pandemic for Companies is contrary to the principle of legal certainty. Legislation that regulates payment of THR for labourers never mandates payment of THR through an agreement. If an agreement is made by violating the laws and regulations, the agreement is null and void. In other words, the SE regulation is dissynchronized with Act No.13 of 2003 concerning Manpower, Government Regulations No.78 of 2015 concerning Wages and Regulation of the Minister of Manpower No.6 of 2016 concerning THR for Workers/labourers $n$ the company.

When agreement on THR payment is not reached, the legal consequences for labourers and entrepreneurs are the accumulation of industrial relations disputes. Due to the mechanism regulated and provided by the Act No. 2 of 2004 concerning Settlement of Industrial Relations Disputes, it has not been able to accommodate the settlement of cases due to cognitive limitations and labour skills on the rules a limited number of industrial relations mediators. Thus the fulfilment of labourers' rights to receive THR during the Covid-19 pandemic is merely a dream.

The formulation of THR payment for labourers during the Covid-19 pandemic should not change the existing regulations and have been enacted. It does not need SE as it is currently issued. THR is an obligation of the entrepreneur. Suppose the employer cannot afford the payment. In that case, the incapacity is the difference that must be borne by the government as a form of consistency in the values of the Pancasila industrial relations.

New regulation to resolve THR payment problems during the Covid-19 pandemic should not change the substance of the existing regulations that may lead to a new problem. It includes legal certainty and justice for labourers and causes dis-synchronization of rules and regulations. The Covid-19 pandemic period that caused the slack of business world demanded concrete gov- 
ernment intervention to provide THR subsidies for labourers. Employers are also entitled to get protection, at least, to survive to save labours to avoid termination of employment. Considering the balanced legal certainty and justice between labourers and entrepreneurs, it is essential that the Minister of Manpower Circular Letter No. M/6/HI.00.01/V/2020 concerning the Implementation of the Religious Holiday Allowance (THR) of 2020 in Companies during The Covid-19 pandemic is revoked and declared invalid.

\section{REFERENCES}

Act No. 2 on Industrial Relations Disputes Settlement, Article 1 Paragraph 1 (2004).

Act No. 2 on Industrial Relations Disputes Settlement Article, Article 4 paragraphs (1) and Article 3 (3). (2004).

Act No. 2 on Industrial Relations Disputes Settlement Article 3 paragraphs (1) and (2) (2004).

Act No. 2 on Industrial Relations Disputes Settlement Article 8 (2004).

Arsalan, Haikal, and Dinda Silviana Putri. "Reformasi Hukum Dan Hak Asasi Manusia Dalam Penyelsaian Perselisihan Hubungan Industrial." Jurnal HAM 11, no. 1 (2020): 40. http://dx.doi.org/10.30641/ham.2020.11.39-50.

Article 1335 of the Civil Code (n.d.).

Article 1337 of the Civil Code (n.d.).

Azis, Abdul, Aan Handriani, and Herlina Basri. "Perlindungan Hukum Hak Pekerja Pada Perjanjian Kerja Waktu Tertentu Dalam Ketenagakerjaan.” Surya Kencana Satu: Dinamika Masalah Hukum Dan Keadilan 10, no. 1 (2019): 59-74. https://doi.org/ 10.32493/jdmhkdmhk.v10i1.3175.

Budiono, Abdul Rachmad. Hukum Perburuhan. Jakarta: Permata Puri Media, 2009.

Bureau, Ministry of Manpower's Public Relation. "Kemnaker: Pegawai Mediator Hubungan Industrial Siap-Siaga Kawal Posko THR,” 2020. https://kemnaker.go.id/news/detail/.

Cahyadi, Irwan Adi. "Kedudukan Hukum Surat Edaran Mahkamah Agung (SEMA) Dalam Hukum Positif Di Indonesia." Jurnal Hukum 3 (2014). http://hukum. studentjournal.ub.ac.id/.

Fakhrurraji, Alzikri. "Implementasi Perundang-Undangan Ketenagakerjaan Terhadap Buruh Pasar Ditinjau Dari Perspektif Keadilan.” Jurnal Hukum Sekolah Tinggi Ilmu Hukum Muhammdiyah Aceh Tengah 4, no. 1 (2018): 31-44. https://doi.org/10.32661/resam.v4i1.7.

Hakim, Sugeng Santoso. "Kekhususan Hukum Acara Pengadilan Hubungan Industrial." Jurnal Hukum Jatiswara 34, no. 1 (2019): 11-25. https://doi.org/10.29303/jaiswara.v34i1.189.

Harianto, Aries. Hukum Ketenagakerjaan, Makna Kesusilaan Dalam Perjanjian Kerja. Yogyakarta: Laksbank, 2016.

_. "Makna Tidak Bertentangan Dengan Kesusilaan Sebagai Syarat Sah Perjanjian Kerja." Brawijaya, 2013.

Hartono, Nanang Rudi, and Amalia Suci Ramadhani. "Tinjauan Yuridis Kebijakan Work From Home Berdasarkan Undang-Undang Ketenagakerjaan.” Jurnal Supremasi 10, no. 2 (2020). https://doi.org/10.35457/supremasi.v10i2.1158. 
Hernoko, Agus Yudha. "Asas Proporsionalitas Sebagai Landasan Pertukaran Hak Dan Kewajiban Para Pihak Dalam Kontrak Komersial." Jurnal Hukum Dan Peradilan 5, no. 3 (2016): 447-66. http://dx.doi.org/10.25216/jhp.5.3.2016.447-466.

Hornby, A S. Oxford Advanced Leaner's Dictionary. New York: Oxford University Press, 1995.

Indahsari, Riska Amalia. "Perlindungan Hukum Terhadap Tenaga Kerja Outsourcing Mengenai Pembayaran THR Dalam Pengalihan Kerja.” Jurist-Diction 2, no. 1 (2019): 292-309. https://doi.org/10.20473/jd.v2i1.12113.

Indonesia, CNN. "Bukan 2 Juta, Kadin Sebut Korban PHK Akibat Corona 15 Juta." CNN Indonesia, 2020. https://www.cnnindonesia.com/ekonomi/20200501181726-92-499298/ bukan-2-juta-kadin-sebut-korban-phk-akibat-corona-15-juta.

Jemadi, and Siti Noor Hidayati. "Analisis Faktor-Faktor Yang Mempengaruhi Potensi Mogok Kerja Karyawan Di Yogyakarta." Jurnal Maksipreneur 1, no. 2 (2012): 46. http://dx.doi.org/10.30.588/jmp.v1i2.74.

Julyano, Mario, and Aditya Yuli Selisyawan. "Pemahaman Terhadap Asas Kepastian Hukum Melalui Kontruksi Penalaran Positivisme Hukum.” Jurnal Crepido 1, no. 1 (2019): 13-22. https://doi.org/10.14710/crepido.1.1.13-22.

Kusmayanti, Hazar, Agus Mulya Karsona, and Efa Laela Fakhriah. "Penyelesaian Perselisihan Hubungan Industrial Melalui Pengadilan Hubungan Industrial Pengadilan Negeri Padang Kelas I (A).” Jurnal Hukum Acara Adhaper 6, no. 1 (2020): 37.

Mertokoesumo, Sudikno. Mengenal Hukum. Yogyakarta: Liberty, 1999.

Merzuki, Peter Mahmud. Penelitian Hukum. Jakarta: Prenada Media, 2005.

Nalle, Victor Imanuel W. "Kewenangan Yudikatif Dalam Pengujian Peraturan Kebijakan (Kajian Putusan Mahkamah Agung Nomor 23 P/HUM/2009)." Jurnal Yudisial 6, no. 1 (2013): 33-47. http://dx.doi.org/10.29123/jy.v6i1.117.

Nola, Luthvi Febryka. "Pengaturan Dan Penegakan Hukum Tinjangan Hari Raya Untuk Pekerja." Info Singkat Hukum IV, no. 16 (2012): 1-4.

Philipus M. Hadjon, Tatik Sri Djatmiati. Argumentasi Hukum. Yogyakarta: Gajah Mada University Press, 2005.

Poesoko, Herowati. Parate Executie Obyek Hak Tanggungan. DHM Meuwis. Yogyakarta: Laksbang Presindo, 2007.

Prajnaparamitha, Mahendra Ridwanul Ghoni dan Kanyaka. "Perlindungan Status Kerja Dan Pengupahan Tenaga Kerja Dalam Situasi Pandemi COVID-19 Berdasarkan Perspektif Pembaharuan Hukum." Administrative Law \& Governance Journal 3, no. 2 (2020): 26212781. https://doi.org/10.14710/alj.v3i2.314-328.

Prayogo, R. Tony. "Penerapan Asas Kepastian Hukum Dalam Peratran Mahkamah Agung Nomor 1 Tahun 2011 Tentang Hak Uji Materiil Dan Dalam Peraturan Mahkamah Konstitusi Nomor 06/PMK/2005 Tentang Pedoman Beracara Dalam Pengujian UndangUndang." Jurnal Legislasi Indonesia 13, no. 2 (2016): 191-202.

S, Laurensius Arliman. "Perkembangan Dan Dinamika Hukum Ketenagakerjaan Di Indonesia." Jurnal Selat 5, no. 1 (2017): 74-87. https://ojs.umrah.ac.id/index.php/selat/article/view/215.

S, Ujang Charda. "Karakteristik Undang-Undang Ketenagakerjaan Dalam Perlindungan Hukum 
Terhadap Tenaga Kerja." Jurnal Wawasan Hukum 32, no. 1 (2015): 7. http://dx.doi.org/10.25072/jwy.v32i1.86.

Safa'at, Jimly Assadiqy and Ali. Teori Hans Kelsen Tentang Hukum. Jakarta: Sekretariat Jenderal dan Kepaniteraan Mahkamah Konstitusi RI, 2006.

Sajou, Daniel Marshal. "Kerenhapukh Milka Tarmadi Putri Dan Niken Febriana Dwi, ”Peran Negara Atas Perlindungan Hukum Tenaga Kerja Indonesia Pada Masa Pandemi Covid19"." Jurnal Syntax Transformation 1, no. 8 (2020): 2721-3854. https://jurnal. syntaxtransformation.co.id/index.php/jst/article/view/137.

Sandi, Ferry. "THR Tahun Ini Paling Parah, Pengaduan THR Melonjak 70\%." CNBC Indonesia, 2020. https://www.cnbcindonesia.com/news/20200520141059-4-159866/thr-tahun-inipaling-parah-pengaduan-thr-melonjak-70.

Suhartoyo. "Perlindungan Hukum Bagi Buruh Dalam Sistem Hukum Ketenagakerjaan Nasional." Administrative Law \& Governance Journal 2, no. 2 (2019): 326-36. https://doi.org/10.14710/alj.v2i2.326-336.

Sulardi, and Yohana Puspitasari Wardoyo. "Kepastian Hukum, Kemanfaatan, Dan Keadilan Terhadap Perkara Pidana Anak." Jurnal Yudisial 8, no. 3 (2015): 251-68. https://doi.org/http://dx.doi.org/10.29123/jy.v8i3.57.

Syafrida, Safrizal, and Reni Suryani. "Pemutusan Hubungan Kerja Masa Pandemi Covid-19 Perusahaan Terancam Dapat Dipailitkan.” Pamulang Law Review 3, no. 1 (2020): 19-30. https://doi.org/10.32493/palrev.v3i1.6532.

The Act No. 13 of 2003 on Manpower along with regulations other than Circular of the Minister of Manpower No.M/6/HI.00.01/V/2020 concerning the Implementation of the Religious Holiday Allowance (THR) of 2020 in the Company during Covid-19 Pandemic (n.d.).

Vijayantera, I Wayan Agus. "Pengaturan Tunjangan Hari Raya Keagamaan Sebagai Hak Pekerja Setelah Diterbitkan Peraturan Menteri Tenaga Kerja Nomor 6 Tahun 2016." Jurnal Kertha Patrika 38, no. 2 (2016): 294.

Wijayanta, Tata. "Asas Kepastian Hukum, Keadilan Dan Kemanfaatan Dalam Kaitannya Dengan Putusan Kepailitan Pengadilan Niaga." Jurnal Dinamika Hukum 14, no. 2 (2014). http://dx.doi.org/10.20884/1.jdh.2014.14.2.291.

Wildan, Muhammad, Nuridin, and Gufron Irawan. "Analisis Perlindungan Hukum Tenaga Kerja Dalam Perjanjian Kerja Waktu Tertentu." Justicia Sains: Jurnal Ilmu Hukum 4, no. 2 (2019): 174-88. http://dx.doi.org/10.24967/jcs.v4i1.414.

Yulianto, Taufiq. "Langkah Hukum Terhadap Pelanggaran Pemberian Tunjangan Hari Raya Keagamaan.” Jurnal Orbith 12, no. 2 (2016): 112-16. http://dx.doi.org/ 10.32497/orbith.v12i2.776. 